\title{
Role of Competitive Strategies in Achieving a Competitive Advantage in the Sudanese Banks
}

\author{
Amir Salim Elsheikh Algarrai, PhD \\ Associate Professor of Business Administration \\ Department of Administrative Sciences \\ Community College, Najran University \\ Saudi Arabia \\ Afaf Omer Fadlalla Shakoot, PhD \\ Business Administration \\ College of Economics \\ Shendi University \\ Republic of Sudan \\ Nandy Abuella Abdu Desougi, PhD \\ Assistant Professor \\ Department of Administrative Sciences \\ Community College \\ Najran University
}

\begin{abstract}
This study aimed to investigate the Sudanese banks 'experience in applying competitive strategies and the roles of these banks in a creating competitive advantage. To achieve the objective of the study, a deductive approach and analytical and descriptive methods were used (questionnaire, interview, and observation). A questionnaire was distributed to the sample 120 participants. 100 completed questionnaires were retrieved which represented a response rate of $88.3 \%$. The findings of the study revealed that $88.6 \%$ of the sample confirmed that the Sudanese banks applied competitive strategies and $90.8 \%$ of the respondents agreed that administrative leaderships in the Sudanese banks supported the application of competition strategies in order to achieve the competitive advantage. Among the most important recommendations were determining the bank's appropriate strategies in the light of the changing environmental conditions and the necessity of scientific selection of administrative leaders in the banks according to the criterion of competence and specialization.
\end{abstract}

Keywords: strategic management, competitive strategies, competitive advantage

\section{Introduction}

Recently, all business organizations (i.e. public or private, productive or service) encounter many challenges due to the rapid and continuous changes imposed by globalization, the free flow of goods, services, the capital, and the intensive use of information and communication technology. These factors have induced extreme competition and amendments in the laws, regulations, patterns and management of organizations. They threaten the survival and continuity of many organizations due to the dynamism, complexity, and instability, which have effect at the internal and external environment of the organization. Therefore, organizations are in a race to obtain sources of excellence over competitors. They look for high profits that enable them to expand their activities and create new investments and increase job opportunities in a manner that leads to the growth and progress of the economies of the countries. As for Sudanese banks, they realize that expanding and gaining the benefits of globalization and the liberalization of markets require new methods that assist them in improving productivity and facing challenges of the competition. This objective can be achieved through employment of strategic management. Strategic management is an intellectual approach that is characterized by modernity, leadership and the ability. It aims to increase the competitive capabilities of the organization and develop its performance. Although many institutions can succeed in short periods with unannounced objectives or intuitive strategies, but in practice it has shown that intuitive strategies cannot be successfully pursued if the size of the organization grows or the surrounding environment changes completely. 
Accordingly, private and public organizations' practice of a strategic management has become an urgent necessity if they want to increase their competitiveness and achieve their objectives. Therefore, this study aims to investigate the role of applying competitive strategies in achieving the competitive advantage in the Sudanese banks.

\subsection{Significance of the study}

The significance of the study lies in its investigation of modern management concepts (i.e. competitive strategies and competitive advantage). Therefore, investigating these concepts in the Sudanese banks give the topic a real importance. The authors' study of scientific framework of the methods of modern management assists in facing administrative problems and dealing with them, within the limitations of internal and external environment changes. The organizations need for this type of management, since it has an active role in drawing plans on scientific background according to the internal and external environment variables of the Sudanese banks. Besides, the study is importance because of its contribution to administrative thought and to the development of the administrative process in business organizations in general and the Sudanese banks in particular. Finally, the study presented results and recommendations that could improve the competitive advantage in the Sudanese banks, and contribute to the studies on the topic of strategic management at a national and international levels

\subsection{Problem statement}

Competition is a distinctive characteristic of business organizations. Because of intensive competition, it is difficult for organizations that do not follow competitive strategies to compete and remain in an environment characterized by rapid complexity. It is important for organizations to follow modern administrative methods to overcome the complexities in their work environment to achieve competition advantage through practicing strategic management, competitive strategies and making a good use of external opportunities and internal strengths. The problem statement of the study can be put in the following main question:

What is the role of competition strategies in achieving a competitive advantage?

This question has sub-questions:

1. How can strategic management contribute to creating a clear and comprehensive vision for the organization to achieve a competitive advantage in an environment characterized by frequent changes and developments?

2. What is the relationship of competition strategies with the achievement of the competitive advantage in the Sudanese banks?

\subsection{Hypotheses}

Based on the problem statement and the objectives of the study, the study hypothesizes a relationship between:

1. Administrative leaders' understanding of the methods of strategic management, and their implementation, practice, and achievement of competitive advantage

2. Competitive strategies and achievement of competitive advantage

\subsection{Objectives of the study}

The main objective of the study is to investigate and analyze the relationship between competitive strategies and achievement of competitive advantage. Besides, the study aims to clarify the meaning of this relationship at the level of the banking sector, namely Faisal Islamic Bank, Sudan Islamic Bank, Savings and Social Development Bank). The authors have selected these banks as a model for the rest of the Sudanese banks. To be specific, the study also aims to

1. To introduce the theoretical framework of competitive advantage and competitive strategies.

2. To reveal the extent of awareness of competitive advantage among Sudanese banks' leaders.

3. To unfold the strategy adopted by the Sudanese banks in determining their competitive advantage.

4. To investigate the methods that could improve the Sudanese banks and achieve excellence in their services by adopting competitive strategies that are appropriate for their clients.

\subsection{Limitation of the study}

The study is limited in its scope to the experience of Sudanese banks in achieving competitive advantage, namely Faisal Islamic Bank, Sudan Islamic Bank, Savings and Social Development Bank from 2010-2020. 


\section{Theoretical framework}

\subsection{Competitive Strategies}

Competitive strategies are considered one of the competitive characteristics of organizations through which they can reconcile between experiences and resources on one hand and opportunities and threats within a competitive environment on the other to achieve objectives. Thus, a competitive strategy can be defined as an integrative group of behaviors that lead to achieving a continuous competitive advantage. As for Al-Samiri, 2000, p. 20), the levels of competitive strategies are:

\section{a. Organization Strategy as a Whole}

At this level, the strategy of an organization is concerned with all activities of the organization beginning with stating its mission, identifying its general objectives, and then counting resources and necessary potentials for implementing the whole strategy as a whole integrated unit.

\section{b. Strategy of Business Units}

In contrast with the previous level, this level is of a narrow scope of activities which is concerned with a reconciliation between the objectives of a unit strategy and the strategy of an organization as a whole.

\section{c. Career Strategy}

This strategy is concerned with each job a part (e.g., a production marketing strategy).

\section{Objectives of Competitive Strategies}

Competitive strategies aim at achieving two objectives:

1. Achieving a permanent and ongoing relative advantage by reducing costs.

2. Achieving a permanent and ongoing relative advantage by improving the quality of products to be distinct.

As for the Al-Khozami (2008, p. 302), the strategies of competitive strategies are:

\section{a. Strategy of Cost Leadership}

Strategies of the reduced costs leadership are established based on the ability of an organization to provide goods or services with lower costs than those of the other competitive ones. However, the essential operational assumption for the reduced costs leadership is represented in getting an essential cost advantage than the other competitors that can be passed to customers to get a higher market share.

\section{b. Differentiation Strategy}

This strategy is based on extending the efforts of an organization to produce a differentiated product than those of the other competitors. There are many ways for making a product of an organization distinct than that of the other competitors such as having a variety of shapes, special qualities, excellent services, parts of vehicles, architecture designs, and good performance and reputation. However, the level of success of the differentiation strategies can be increased when the organization enjoys with skills and competencies that can never be imitated easily by other competitors.

\section{c. Focus Strategy}

It is designed to help an organization attract certain customers to industry. Unlike the cost leadership and differentiation strategies designed for a larger market or the industry as a whole, the focus strategy attracts a certain category of customers with a special position. These customers can be special purchasers, a small department in a certain production line, a geographical market in a certain area, or of special preferences and fashions. The main idea of the focus strategy is that the organization should do unique activities that cannot be practiced by other competitive organizations with an abroad production line and lower costs (Khalil, -----, p. 119). This strategy however seeks to utilize from a competitive advantage in the targeted market sector by introducing products lower than those of the other competitors in price (i.e., focusing on lowering costs). Or by introducing distinguished products in quality (i.e., focusing on differentiation). Meaning, the organization can adopt one of the two following shapes:

\section{Focus Strategy on Costs}

It is a competitive strategy which depends on a cost reduction by focusing on a certain market sector or a group of customers to serve them as a small sector rather than a market as a whole. 


\section{Focus on Differentiation}

In this case, any organization must follow the same steps available in the strategy of producing a special product, rather than those of the other competitors, focusing only on a certain market sector or certain customers.

\section{Barriers of a Competitive Advantage Acquisition}

Acquiring a competitive advantage by an organization is not an easy task to do. That is, the organization may encounter a number of barriers that may detain it from acquiring a competitive advantage and, then, a competitive strategic position in market. Below are some barriers which can be categorized into internal and external briberies (Othman, 2017, p. 62).

\section{Internal Barriers}

They refer to internal obstacles encountered by an organization in its environment in country, namely:

a. Absence of a successful management leadership results in detaining the management development. Any weakness appears in this state is attributed to the absence of competent leaderships who could develop the skills of employees.

b. Lack of a positive control that ends any misconducts in an organization.

c. Absence of transparency when removing employees' negative attitudes in an organization.

d. Inability of an organization to provide fast necessary information in support of the decision-making process and rationalization.

e. Lack of using technology, mass media, coping with recent developments, etc.

\section{External Barriers}

They refer to a variety of external obstacles encountered by an organization outside its environment in country, namely:

a. Global markets and regional blocs put either obstacles or motivations for marketing

b. Availability of legislatives, laws, and controls serving foreign organizations at the expense of national ones.

c. Availability of organizations allied internationally that can difficultly be completed by others.

d. Twisting from competitions in goods and services into competitions in knowledge.

e. Changing the special criteria of the quality international standards.

f. Lack of adherence to the quality international standards.

g. Weaknesses in education systems.

h. Lack of interest in research.

\subsection{Competitive Advantage}

The concept of "competitive advantage" posits a great importance nowadays because business organizations are living in dramatic, changeable and complex environments showing different phenomena such as globalization, non-organized markets, changeable customer's requirements, increasing competition over products, and a revolution of information and telecommunications technology.

Due to the increasing competition among organizations, every organization must develop plans and strategies to be able to compete others, keep its current customers, and attract other new ones. So, a contemporary organization, in strongly competitive environments, seeks to gain more competitive advantages than the other operating organizations in the same activity. This in turn can be achieved by identifying aspects of strength and weakness of resources and changing the aspects of strength into competitive advantages to encounter all competitors in markets. This however can be done by adding a value to the customer and achieving distinction (Al-Roosan, 2007, p. 80).

\section{Definition of Competitiveness}

The term "competitiveness" is not limited to a certain field; rather, it can be expressed by different labels as follows:

a. Competition: Linguistically, it means "a predisposition calling for paying efforts for the sake of distinction". It can be defined as "the current or probable crowdedness where a seller can sell independently from others and buyers likewise". 
However, it is a system of economical relationships which involves a number of buyers and sellers, each of them can behave independently for the sake of reaching to the maximum advantage. While, the organization must always be preoccupied with its competitive position in order to either develop it, follow it up, protect it, or keep it.

b. Competitiveness: It confirms the race-and-overcome phenomenon which is derived from "competition" which in turn refers to beating oneself up and imitating what is best to be followed.

c. Competitive Ability: It is an organization's degree of success in achieving its objectives, sustaining its competitive positions, and developing better competitive positions. All these merits can be done by minimizing the percentage of error-making and real shortcomings, showing interest and creativity, and considering cost of sales. In addition, the competitive ability is defined as the ability of producing goods and services that confront the international competition to make citizens of a certain country enjoy with a level of acceptable and sustained living conditions (Al-Roosan, 2007, p. 80).

All in all, there is no agreement among authors in regard to the definition of "competitiveness". Some of them believe that "competitiveness" is a broad term that includes an entire productivity, levels of living conditions, and an economic development. In contrast, others believe that "competitiveness" is a narrow concept based on competition of price and trade and differs according to the institution where it is practiced in such as companies, sectors, states, etc. The following definitions clarify this point:

a) Project Competitiveness (company): Competitiveness refers to the ability of providing customers with capable and effective products and services in the international market than those of the other competitors. That is, the company that adopts this policy can continuously succeed internationally in the absence of the related government's support and production. This can be done by increasing the productivity of the production factors employed in the production process (i.e., work, capital, and technology). However, the competitiveness of a company can be measured by a number of indicators, notably advantage and ratio of development.

b) Sector Competitiveness: It means the ability of a certain industry sector in a state to achieve an ongoing success in the international markets without any governmental support and protection. The most important indicators of advantage are trade scale, total of direct foreign investment, and measurements of cost and quality.

c) State Competitiveness: It is the ability of a state to achieve a higher level of income for its individuals. In addition, it is defined as the ability to withstand competitors in order to achieve the objectives of profitability, stability, expansion, innovation and renewal. The companies and businessmen seek to improve competitive positions periodically due to the stability of local and global variables (Al-Najjar, 2000, p. 10). Types of Competitiveness

2.3.1. Competitiveness of Cost and Price: A country with lower costs can export goods to the foreign markets better.

2. Non-Price Competitiveness: It involves an appropriate qualitative competition, delivery facilities, and innovation in the country where a unique and innovative quality of products are more appropriate to consumers.

\section{Definition of a Competitive Advantage}

Researchers have found a difficulty in defining the competitive advantage and accordingly, each one has defined it from his/her own point of view and economic orientation. Below are some definitions:

1. It is "the way an organization can distinguish itself from its peers and competitors by, for example, innovating things unknown to them" (Abdulmattaleb, 2010, p. 90).

2. It is "the capacity of an organization to apply production processes that are not applied by other competitive organizations because the latter cannot obtain the necessary resources to adopt such processes".

3. It is "the ability of an organization to start its business in a number of ways that can never be imitated by other competitors easily".

4. The Ministry of Industry and Trade of England defines it as "the ability to produce the required accurate fine-quality at a reasonable price on time. That is, it has the ability to meet the consumers' needs more efficiently than the other projects" (Radhwan, 2011, p. 21)

5. The Ministry of Industry and Trade of England defines it as "the ability to produce the required accurate fine-quality at a reasonable price on time. That is, it has the ability to meet the consumers' needs more efficiently than the other projects" (Radhwan, 2011, p. 21). 
6. It is "the ability of an organization to state and apply strategies that qualify it to a better position achieving a competitive advantage than the other organizations operating in the same activity. This can be achieved when there is a better utilization for potentials and technical, material, financial and information resources, capabilities, competencies and other potentials that enable it to design and implement its competitive strategies.

7. In other words, achieving a competitive advantage is determined by two essential dimensions: the value the customer is aware of and the organization's ability to achieve distinction" (Haider, 2002, p. 8).Tools of a Competitive Advantage

\section{Quality}

Quality is defined as making or implementing all characteristics and specifications of goods or services to meet consumers' needs when they buy and use them. Worldwide, many companies pay more attention to quality because it is an important strategic dimension that focuses on reducing costs and increasing the consumers' satisfaction. To compete, any organization depends on quality, prices and time of delivery.

\section{Time}

Organizations provide great importance to time because when a higher-quality performance is achieved on time increases sales revenue and reduces costs. There are two operational time scales:

a. Customer Response Time: It is the time between the customer's order for a product or service till the product or service is offered.

b. Performance: It is the time of delivery which indicates the degree of commitment to a planned delivery time or service performance. This in turn provides the organization with the customers' confidence and ensures future dealings.

\section{Price}

It is the value of a product or service that is determined by the purchasing power (i.e., supply and demand).

\section{Dimensions of Competitive Advantage}

Competitive dimensions refer to characteristics confirmed by an organization when offering its products. By these characteristics, it can obtain advantages more than the other competitors. So, and to exceed its competitors, it must show one or more of the below dimensions.

\section{Quality}

A customer seeks to get higher-quality goods by making a tradeoff between quality and price. On this base, organizations seek to fulfill the customer's orders by offering products that meet his/her expectations. Thus, quality is considered as the most important element of the competitive advantage.

Moreover, achieving higher-quality products and services by an organization imposes a higher price on customers which in turn may create a competitive advantage for the organization concerned. Thus, the quality is measured by the organization's ability to introduce a superior, unique or expensive product from its customer's point of view. This, in effect, offers higher-quality products of special features and post-sale services. Accordingly, the organization can be distinct from its competitors when being able to acquire unique characteristics that attract the customer. From a customer's perspective, quality is more comprehensive and must be paid a special concern because:

a. it is the most important feature of a product or service to ensure continuity, safety, and ease of use; and b. it indicates the accuracy, response, and continuity of a product or what is called "post-sale services".

\section{Cost}

It is the ability of an organization to reduce the cost of its goods and services, compared to its competitors, achieving ultimately great returns. This in turn requires identifying its critical activities that form an important source of distinction. In implication, a lower cost is considered as the first competitive advantage imposed by an organization at a lowest cost compared to other competitors. This can be achieved by improving productivity, efficiency and tight cost control. Reducing costs however is the most obvious way to achieve a competitive advantage. Customers select lower prices, which must be in balance with cost, because the price is the estimated value paid against owing the product to be offered to consumers for benefits. Economists focus on the concept of "value and benefits" in determining price because the benefit produces the value which (the latter) is measured by price. The dimensions of the lower cost are characterized by introducing low-cost goods and services in addition to reducing changeable, marketing, and operational costs and supporting research and development activities. 
By information technology, the organization can reduce the cost advantage by using a number of techniques such as coordination between departments, simplification of procedures, reduction of inventory and workforce, and reorganization.

\section{Creativity}

It refers to all developments occurring to products and services offered by an organization, its structure, management techniques and strategies. Creativity can be achieved by introducing a new product or working in a different way from competitors. Whilst, innovation is considered as one of the competitive bases of advantage that allows the organization to be distinguished and imposes higher prices or reduces the production cost. This allows for creative development and work so as to achieve creativity in the outputs or processes used. Producing products, or introducing services, or using new revenues for the first time by an organization means doing certain technological changes to meet the needs of the market to consequently achieve a competitive advantage. So, the organizations that seeks creativity, as a competitive precedence, must focus on research and development because the important factor for confronting adversaries is its ability to innovate and introduce new products.

\section{Flexibility and Delivery}

Both lower cost and good quality are no longer competitive when the customers' desires get increased and his/her love for change and diversification becomes rather rapid. As a result, flexibility is now the critical competitive advantage because production becomes customer-driven. That is, there is a sense of adaptation between the customer's unique needs and his/her changing product designs, i.e. flexibility. So, flexibility means the ability of processes to change from a product to another or from a customer to another at the lowest cost. Some organizations show rapid processes in responding to the customer's requests confirming that the time of introducing services is an important factor for determining quality and cost. In other words, the speed of introducing services indicates a rapid response to the customer's requests which is measured by a waiting time or what is known as the "fast delivery time" spent between order delivery and fulfillment (Ahmed, 2011, p. 33).

\section{Competitive Advantage}

Some writers believe that the competitive advantage is linked to two basic dimensions: customer value and distinction.

\section{Customer Value}

Organizations exploit different possibilities for improving the value of goods and services known to the customer. In effect, this contributes to building their competitive advantage in that the value, in addition to price and quality, ensures persuasion in products or services and post-sale services.

\section{Distinction}

A competitive advantage can be achieved by offering goods or services that competitors cannot emulate or copy. However, there are a number of sources that lead to distinction, notably financial resources, intellectual capital, and organizational capabilities (Abu Bakr, 2012, p. 15).

\section{Competitive Advantage Indicators}

There are a number of indicators used to indicate the competitive advantage of an organization such as profitability, market share, sales volume, consumer satisfaction, product diversity, etc. But the most commonly used indicators are profitability, market share, and sales volume due to the availability of data that can be calculated accurately (AlAttoom, 2009, p. 47).

\section{Profitability}

It is defined as "a measurement used to evaluate the performance of organizations by calculating the ratio of the net income relative to assets or investments". Profitability can be maximized by improving the project investments, using modern techniques and utilizing resources better.

\section{Market Share}

Market share is a measurement used to distinguish between market winners and losers by calculating the organization's share of sales in the market and comparing it with major competitors. In addition, it is used to indicate the organization's market position and its decline showing any occurring problem the management has to resolve. 


\section{Sales Volume}

Sales volume is an indicator for a work success and a market share of an organization. Most organizations seek to set an objective for the amount of sales sought to track performance and the extent of success in achieving the set objectives.

\section{Previous Studies}

Abu Qenaya (2002) studied 'concepts of a strategic management with management leaderships and its effect on enterprise development". He aimed at identifying: a) the extent of awareness in concepts and techniques of the strategic management among the management leaders and the relationship between the level of awareness and the degree of practice and its impact on the effectiveness and development of some private and public enterprises in Sudan. He also studied the factors that detain practicing the strategic management with its comprehensive and formal forms in Sudanese enterprises. The main problem of the study was that many Sudanese enterprises failed to achieve development and continuity because of weakness and practicing traditional management techniques. The study used a historical and descriptive approaches to collect the required data. The study revealed a number of findings, notably, many Sudanese organizations had no clear mission resulting in encountering difficulties when achieving their objectives. Consequently, they could not develop and continue. Moreover, there was a weakness in practicing and applying the strategic management.

Al-Moshari (2004) studied the effect of a strategic management on the cement sector in the Kingdom of Saudi Arabia, aiming at exploring the most important dimensions of the strategic management of marketing that affected the increase of the values of the private enterprises. The main problem of the study was that the cement trade and industry in the Kingdom of Saudi Arabia was affected by the growth and decline of the economy. The study revealed a number of findings; notably, there was a weakness in the strategic management practice and a lack in the strategic planning and marketing in particular in the targeted companies.

Al-Ameri (2006) conducted a study on the effect of a strategy on developing performance at the Islamic Banks in Yemen to assess the level of the strategic management practice in the Islamic banks in Yemen. The primary problem of the study was that the banks showed a poor interest in practicing the strategic management. A descriptive approach was used to collect the required data. It was found high interest in the strategic management practice in the Islamic banks in Yemen. However, there were factors limited the practice of the strategic management such as a lack in the specialized cadres in the strategic planning field, instability of the country, and no clear financial policy.

Harharah (2008) studied the effect of applying the strategic management approach on the performance of Trade Banks in the United Arab of Emirates. The study aimed to identify the extent of interest and awareness in the strategic management in the senior management of the trade banks in the UAE. Further, it investigated the aspects of strengths and weaknesses in the performance of the targeted banks. Both historical and descriptive approaches were used to collect the data. The most significant findings of the study revealed that there were no weaknesses in practicing the strategic management in the UAE banks. However, there was a relationship between practicing the strategic management and the administrative financial performance in those banks.

Tabeedi (2010) conducted a study on the effect of the strategic management on the efficiency and effectiveness of performance. It aimed at identifying: the extent of applying and practicing the strategic management in the Sudanese telecommunication sector, and the level of performance of the operating telecommunication companies in Sudan. The problem of the study was in the extent of applying and practicing the strategic management in the Sudanese communications sector and the impact of that application on the efficiency and effectiveness of the performance in this vital sector. A case study in addition to a descriptive approach were used to collect the required data. The most significant findings reached were: both senior and middle managements at the telecommunication companies were familiar with the concepts and techniques of the strategic management and the application of the strategic management led to the effectiveness of performance at the telecommunication companies. Besides, they had a general interest in training, but there was a lack of training in the strategic management.

Finally, Shaker (2015) investigated the sequential effect of business strategies on non-governmental banks in general and the types of strategies adopted by the management of the Iraqi banks to achieve a sustainable competitive advantage. The problem of the study indicated ambiguity and weakness in identifying the type of strategies and their effect in achieving competitive advantage in those banks. Besides, the banks face a number of challenges increasing improvement and development. 
The study revealed a number of findings; the most significant ones were: the resources and reputation of the banks, in comparison with the other competitive banks, were rare as shown when offering their banking services; and the management of the banks was always careful in offering distinct services by using modern techniques that enabled employees to offer higher quality services consistent with customers' expectations to achieve a sustainable competitive advantage.

\section{Research Methodology}

The study aimed at identifying the role of the competition strategies in achieving the competitive advantage in the Sudanese banks: a field study applied on the Sudanese Islamic Bank, Saving and Social Development Bank, and Faisal Islamic Bank. To achieve this objective, this section is devoted to describe the procedures used to collect the data, namely research methods, sampling, research tools, validity and reliability tests, and the statistical techniques used to analyze the (primary) data.

The case study followed a descriptive approach. A questionnaire was used as a research tool to collect the data including a letter to the respondents to inform him/her about the topic of the study and its objectives. It included two sections:

First Section: It shows the personal information of the respondent such as gender, age, marital status, qualification, scientific major, job position, and years of experience.

Second Section: It involves two areas:

First Area: It is designed to test the $1^{\text {st }}$ hypothesis of the study "there is a statistically significant relationship between the competitive strategies and achievement of the competitive advantage" which includes eight items.

Second Area: It is designed to test the $2^{\text {nd }}$ hypothesis of the study "there is a statistically significant relationship between the senior management's understanding, applying, and practicing the strategic management techniques, and achievement of the competitive advantage" which involves seven items.

However, the questionnaire included 15 questions distributed over the hypotheses of the study as shown in Table 1 below:

Table 1 Distribution of Questions over Hypotheses

\begin{tabular}{|c|c|c|}
\hline Questions & No. & Hypotheses \\
\hline From & $1-8$ & $1^{\text {st }}$ Hypothesis \\
\hline From & $9-15$ & $2^{\text {nd }}$ Hypothesis \\
\hline
\end{tabular}

The questions of the questionnaire were introduced to 11 referees specializing in the field of management to test the face validity of the questionnaire and the reliability of the questions involved in case of clarity and wording. Then, the researchers did the modifications suggested by the referees. To test the reliability of the items, a sample of 10 respondents was selected to test the reliability of the questionnaire. Using the techniques of Spearman Brown and Cranach Alpha in purpose, the reliability of the questionnaire scored $82 \%$ and $80 \%$, respectively.

\section{Sampling}

The society of the study was all employees working in the Sudanese Islamic Bank, Saving and Social Development Bank, and Faisal Islamic Bank. The sample of the study was selected purposefully to achieve the objectives of the study. 120 copies of the questionnaire were distributed to the sample; 100 copies of them (83.3\%) were returned back. Table 2 below describes both distributed and back copies of the questionnaire:

Table 2 Distributed and Back Copies of Questionnaire

\begin{tabular}{|l|l|l|}
\hline Description of Questionnaire Distribution & No. & \% \\
\hline Distributed copies & 120 & $100 \%$ \\
\hline Returned Copies & 100 & $83.3 \%$ \\
\hline Unreturned Copies & 20 & $16.7 \%$ \\
\hline Invalid Copies & 0 & $0 \%$ \\
\hline Invalid Copies & 100 & $83.3 \%$ \\
\hline
\end{tabular}


Table 2 shows that the number of the sample who returned the copies of the questionnaire back to the researcher was 100 (i.e., 83.3\%). Statistically speaking, this number was high and therefore the results of the study would be accepted.

\subsubsection{Statistical Techniques}

To address the questions of the study, the data were analyzed statistically using Frequency, Mean, Standard Deviation, and Chi-Square.

4. Data Analysis and Discussion

\subsection{Characteristics of the Sample}

Table 3 below shows the characteristics of the sample:

Table 3 Characteristics of the Sample

\begin{tabular}{|c|c|c|c|c|c|c|c|}
\hline No & Gender & No & $\%$ & No & Major & No & $\%$ \\
\hline 1. & Male & 57 & $57 \%$ & 1. & Business Administration & 25 & $25 \%$ \\
\hline 2. & Female & 43 & $43 \%$ & 2. & Economy & 20 & $20 \%$ \\
\hline \multicolumn{2}{|r|}{ Total } & 100 & 100 & 3. & Accounting & 27 & $27 \%$ \\
\hline No & Age & No & $\%$ & 4. & Banks & 12 & $12 \%$ \\
\hline 1. & Less than 30 years & 37 & $37 \%$ & 5. & Computer & 6 & $6 \%$ \\
\hline 2. & $\begin{array}{c}30 \text { years and less than } \\
40 \text { years }\end{array}$ & 38 & $38 \%$ & 6. & Accounting \& Funding & 10 & $10 \%$ \\
\hline 3. & $\begin{array}{c}40 \text { and less than } 50 \\
\text { years }\end{array}$ & 18 & $18 \%$ & 7. & Other & 0 & $0 \%$ \\
\hline 4. & $\begin{array}{c}50 \text { years and less than } \\
60 \text { years }\end{array}$ & 6 & $6 \%$ & & Total & 100 & $100 \%$ \\
\hline 5. & 60 years and older & 1 & $1 \%$ & No & Years of Experience & No & $\%$ \\
\hline \multicolumn{2}{|r|}{ Total } & 100 & $\begin{array}{c}100 \\
\%\end{array}$ & 1. & Less than 5 years & 39 & $39 \%$ \\
\hline No & Marital Status & No & $\%$ & 2. & $5-10$ years & 45 & $45 \%$ \\
\hline 1. & Single & 39 & $39 \%$ & 3. & $10-15$ years & 12 & $12 \%$ \\
\hline 2. & Married & 59 & $59 \%$ & 4. & 15 years and more & 4 & $4 \%$ \\
\hline 3. & Widower & 1 & $1 \%$ & \multicolumn{2}{|r|}{ Total } & 100 & $100 \%$ \\
\hline 4. & Divorced & 1 & $1 \%$ & No & Job Title & No & $\%$ \\
\hline \multicolumn{2}{|r|}{ Total } & 100 & $\begin{array}{c}100 \\
\%\end{array}$ & 1. & Manager & 10 & $10 \%$ \\
\hline No & Qualification & No & $\%$ & 2. & Financial Manager & 1 & $1 \%$ \\
\hline 1. & Secondary & 3 & $3 \%$ & 3. & Head of Department & 25 & $25 \%$ \\
\hline 2. & University & 69 & $69 \%$ & 4. & Employee & 64 & $64 \%$ \\
\hline 3. & Post Graduate & 28 & $28 \%$ & 5. & Other & 0 & $0 \%$ \\
\hline \multicolumn{2}{|r|}{ Total } & 100 & $\begin{array}{c}100 \\
\%\end{array}$ & \multicolumn{2}{|r|}{ Total } & 100 & $100 \%$ \\
\hline
\end{tabular}

\subsection{Data Analysis and Discussion}

\subsubsection{Data Analysis of the $1^{\text {st }}$ Hypothesis}

There was a statistically significant relationship between the competitive strategies and achievement of the competitive advantage. To know the opinions of the respondents about this relationship, the analytical descriptive analysis was used.

\subsubsection{Frequency of the $1^{\text {st }}$ Hypothesis Statements}

Table 4 below describes the frequency of the items that address the relationship between the competitive strategies and the achievement of the competitive advantage: 
Table 4 Frequency of the $1^{\text {st }}$ Hypothesis statements

\begin{tabular}{|c|c|c|c|c|c|c|c|c|c|c|c|}
\hline \multirow[b]{2}{*}{ No } & \multirow[t]{2}{*}{ statements } & \multicolumn{2}{|c|}{$\begin{array}{l}\text { Strongly } \\
\text { Agree }\end{array}$} & \multicolumn{2}{|c|}{ Agree } & \multicolumn{2}{|c|}{ Neutral } & \multicolumn{2}{|c|}{ Disagree } & \multicolumn{2}{|c|}{$\begin{array}{l}\text { Strongly } \\
\text { Disagree }\end{array}$} \\
\hline & & No & $\%$ & No & $\%$ & No & $\%$ & No & $\%$ & No & $\%$ \\
\hline 1 & $\begin{array}{l}\text { The bank achieves a competitive } \\
\text { advantage by adopting general } \\
\text { competitive strategies. }\end{array}$ & 59 & $59 \%$ & 34 & $34 \%$ & 5 & $5 \%$ & 2 & $2 \%$ & 0 & $0 \%$ \\
\hline 2 & $\begin{array}{l}\text { The bank changes its different } \\
\text { activities to confront competitors. }\end{array}$ & 53 & $53 \%$ & 36 & $36 \%$ & 8 & $8 \%$ & 3 & $3 \%$ & 0 & $0 \%$ \\
\hline 3 & $\begin{array}{l}\text { The bank adopts a policy that cannot } \\
\text { be imitated by other competitors. }\end{array}$ & 50 & $50 \%$ & 32 & $32 \%$ & 11 & $11 \%$ & 7 & $7 \%$ & 0 & $0 \%$ \\
\hline 4 & $\begin{array}{l}\text { The bank offers banking services that } \\
\text { coincide with customers' expectations. }\end{array}$ & 41 & $41 \%$ & 47 & $47 \%$ & 11 & $11 \%$ & 1 & $1 \%$ & 0 & $0 \%$ \\
\hline 5 & $\begin{array}{l}\text { The strategy of cost leadership } \\
\text { reduces the cost of services offered by } \\
\text { the bank. }\end{array}$ & 45 & $45 \%$ & 42 & $42 \%$ & 9 & $9 \%$ & 3 & $3 \%$ & 1 & $1 \%$ \\
\hline 6 & $\begin{array}{l}\text { The bank enjoys excellent good } \\
\text { relation with customers. }\end{array}$ & 54 & $54 \%$ & 37 & 37 & 8 & $8 \%$ & 1 & $1 \%$ & 0 & $0 \%$ \\
\hline 7 & $\begin{array}{l}\text { The bank is keen to develop its } \\
\text { programs and technical activities. }\end{array}$ & 54 & $54 \%$ & 36 & $36 \%$ & 5 & $5 \%$ & 4 & $4 \%$ & 1 & $1 \%$ \\
\hline 8 & $\begin{array}{l}\text { Excellence strategy encourages team } \\
\text { work to suggest new ideas at the bank. }\end{array}$ & 54 & $54 \%$ & 34 & $34 \%$ & 11 & $11 \%$ & 2 & $2 \%$ & 0 & $0 \%$ \\
\hline \multicolumn{2}{|c|}{ Total } & 410 & 51.3 & 298 & 37.3 & 67 & 8.3 & 23 & 2.9 & 2 & 0.2 \\
\hline
\end{tabular}

Table 4 above shows that $88.6 \%$ of the sample agreed on all items that addressed the relationship between the competitive strategies and achievement of the competitive advantage while those who disagreed on this relationship were $3.1 \%$. The percentage of those who were neutral was $8.3 \%$.

\subsubsection{Analysis of the $1^{\text {st }}$ Hypothesis Items}

Table 5 below shows the Mean (M), Standard Deviation (SD), and the relative importance (\%) and the rank (R) of the items in accordance with the sample's responses. If the real mean of the items is greater than the assumed mean (3) and the percentage is greater than $60 \%$, the item is positive (i.e., it is agreed upon by the sample). However, If the real mean of the items is less than the assumed mean (3) and the percentage is less than $60 \%$, the item is negative (i.e., it is disagreed upon by the sample).

Table 5 Descriptive Analysis of the $1^{\text {st }}$ Hypothesis Items

\begin{tabular}{|l|l|l|l|l|l|l|}
\hline $\begin{array}{l}\mathbf{N} \\
\mathbf{0}\end{array}$ & Items & $\mathbf{M}$ & $\mathbf{S D}$ & $\mathbf{6}$ & Level of Response & $\mathbf{R}$ \\
\hline $\mathbf{1}$ & $\begin{array}{l}\text { The bank achieves a competitive advantage } \\
\text { by adopting general competitive strategies. }\end{array}$ & 4.50 & 0.689 & $90.0 \%$ & Very High & 1 \\
\hline $\mathbf{2}$ & $\begin{array}{l}\text { The bank changes its different activities to } \\
\text { confront competitors. }\end{array}$ & 4.39 & 0.764 & $87.8 \%$ & Very High & 4 \\
\hline $\mathbf{3}$ & $\begin{array}{l}\text { The bank adopts a policy that cannot be } \\
\text { imitated by other competitors. }\end{array}$ & 4.25 & 0.914 & $85.0 \%$ & Very High & 8 \\
\hline $\mathbf{4}$ & $\begin{array}{l}\text { The bank offers banking services that } \\
\text { coincide with customers' expectations. }\end{array}$ & 4.28 & 0.697 & $85.6 \%$ & Very High & 6 \\
\hline $\mathbf{5}$ & $\begin{array}{l}\text { The strategy of cost leadership reduces the } \\
\text { cost of services offered by the bank. }\end{array}$ & 4.27 & 0.827 & $85.4 \%$ & Very High & 7 \\
\hline $\mathbf{6}$ & $\begin{array}{l}\text { The bank enjoys excellent good relation } \\
\text { with customers. }\end{array}$ & 4.43 & 0.728 & $88.6 \%$ & Very High & 2 \\
\hline $\mathbf{7}$ & $\begin{array}{l}\text { The bank is keen to develop its programs and } \\
\text { technical activities. }\end{array}$ & 4.38 & 0.838 & $87.6 \%$ & Very High & 5 \\
\hline $\mathbf{8}$ & $\begin{array}{l}\text { Excellence strategy encourages team work to } \\
\text { suggest new ideas at the bank. }\end{array}$ & 4.40 & 0.752 & $88.0 \%$ & Very High & 3 \\
\hline Total & $\mathbf{4 . 3 6}$ & $\mathbf{0 . 7 7 6}$ & $\mathbf{8 7 . 3 \%}$ & Very High & \\
\hline
\end{tabular}




\subsubsection{Chi-Square Test}

To identify whether or not there were statistically significant differences between the those who agreed and those who disagreed upon items, Chi-square test was used. The results of the test are shown in Table 6 below:

Table 6 Results of Chi-Square Test

\begin{tabular}{|c|c|c|c|c|c|c|}
\hline $\mathbf{N}$ & Items & $\begin{array}{l}\text { Chi } \\
\text { Value }\end{array}$ & DF & t- Value & P-value & $\mathbf{P}$ \\
\hline 1 & $\begin{array}{l}\text { The bank achieves a competitive advantage by adopting } \\
\text { general competitive strategies. }\end{array}$ & 86.6 & 3 & 7.81 & 0.000 & Significant \\
\hline 2 & $\begin{array}{l}\text { The bank changes its different activities to confront } \\
\text { competitors. }\end{array}$ & 67.1 & 3 & 7.81 & 0.000 & Significant \\
\hline 3 & $\begin{array}{l}\text { The bank adopts a policy that cannot be imitated by other } \\
\text { competitors. }\end{array}$ & 47.7 & 3 & 9.48 & 0.000 & Significant \\
\hline 4 & $\begin{array}{l}\text { The bank offers banking services that coincide with } \\
\text { customers' expectations. }\end{array}$ & 60.4 & 3 & 7.81 & 0.000 & Significant \\
\hline 5 & $\begin{array}{l}\text { The strategy of cost leadership reduces the cost of services } \\
\text { offered by the bank. }\end{array}$ & 94.0 & 4 & 7.81 & 0.000 & Significant \\
\hline 6 & The bank enjoys excellent good relation with customers. & 74.0 & 3 & 7.81 & 0.000 & Significant \\
\hline 7 & $\begin{array}{l}\text { The bank is keen to develop its programs and technical } \\
\text { activities. }\end{array}$ & 112.7 & 4 & 9.48 & 0.000 & Significant \\
\hline 8 & $\begin{array}{l}\text { Excellence strategy encourages team work to suggest new } \\
\text { ideas at the bank. }\end{array}$ & 67.4 & 3 & 7.81 & 0.000 & \\
\hline \multicolumn{2}{|c|}{ Total } & 85.7 & 76.2 & 4 & 9.48 & 0.000 \\
\hline
\end{tabular}

\subsubsection{Discussion of the Results of the $1^{\text {st }}$ Hypothesis}

Table 4 shows that the majority of the sample agreed on all items designed to address the $2^{\text {nd }}$ hypothesis. All their responses were positive in that the percentage of their total agreement shown in the frequency distribution of the $2^{\text {nd }}$ hypothesis was $88.6 \%$. This percentage indicates that they totally agreed on the contents of the hypothesis in that the level of the agreement was very high. This indicates that all sample agreed on the association between the competitive strategies and achievement of the competitive advantage.

Table 5 shows that the total mean of all items of the hypothesis was greater than the assumed mean (3) according to Likert Scale. This indicates that the attitudes of the sample were positive in that the sample agreed on all items of the hypothesis, $M=4.36, S D=0.776, \%=90$, the relative importance $=78.3 \%$ (very high). This indicates that the majority of the sample agreed on the relationship between the competitive strategies and achievement of the competitive advantage.

Table 6 shows that, based on Chi-square, there were statistically significant differences among items in that the total value of Chi-square of all items was 76.2 at the level $0.000<0.05$. Therefore, there were statistically significant differences between the sample's responses in favor of those who agreed on the items at a very high level of response.

Therefore, based on data analysis, the $1^{\text {st }}$ hypothesis "there was a statistically significant relationship between the competitive strategies and achievement of the competitive advantage" was accepted at a very high level of response.

\subsubsection{Data Analysis of the $2^{\text {nd }}$ Hypothesis}

There was a statistically significant relationship between the senior management's understanding, applying, and practicing the strategic management techniques, and achievement of the competitive advantage. To know the opinions of the respondents about this relationship, the analytical descriptive analysis was used.

\subsubsection{Frequency of the $2^{\text {nd }}$ Hypothesis Items}

Table 7 below describes all frequency of the items that address the relationship between the senior management's understanding, applying, and practicing the strategic management techniques, and achievement of the competitive advantage: 
Table 7 Frequency of the $2^{\text {nd }}$ Hypothesis Statements

\begin{tabular}{|c|c|c|c|c|c|c|c|c|c|c|c|}
\hline \multirow[b]{2}{*}{ No } & \multirow[t]{2}{*}{ statements } & \multicolumn{2}{|c|}{$\begin{array}{l}\text { Strongly } \\
\text { Agree }\end{array}$} & \multicolumn{2}{|c|}{ Agree } & \multicolumn{2}{|c|}{ Neutral } & \multicolumn{2}{|c|}{ Disagree } & \multicolumn{2}{|c|}{$\begin{array}{l}\text { Strongly } \\
\text { Disagree }\end{array}$} \\
\hline & & No & $\%$ & No & $\%$ & No & $\%$ & No & $\%$ & No & $\%$ \\
\hline 1 & $\begin{array}{l}\text { The senior management of the bank seeks to } \\
\text { achieve a good competitive position } \\
\text { continuously. }\end{array}$ & 71 & 71 & 24 & 24 & 4 & 4 & 1 & 1 & 0 & 0 \\
\hline 2 & $\begin{array}{l}\text { The management of the bank delegates } \\
\text { some powers to the employees }\end{array}$ & 61 & 61 & 32 & 32 & 4 & 4 & 3 & 3 & 0 & 0 \\
\hline 3 & $\begin{array}{l}\text { The management of the bank is keen to } \\
\text { train the employees to develop their skills } \\
\text { and abilities. }\end{array}$ & 55 & 55 & 35 & 35 & 8 & 8 & 2 & 2 & 0 & 0 \\
\hline 4 & $\begin{array}{l}\text { The management of the bank adopts a } \\
\text { participation-of-employees technique in } \\
\text { decision-making. }\end{array}$ & 51 & 51 & 32 & 32 & 13 & 13 & 4 & 4 & 0 & 0 \\
\hline 5 & $\begin{array}{l}\text { The management of the bank encourages } \\
\text { employees to create a motivative } \\
\text { environment for creativity and } \\
\text { distinctiveness. }\end{array}$ & 49 & 49 & 43 & 43 & 5 & 5 & 2 & 2 & 1 & 1 \\
\hline 6 & $\begin{array}{l}\text { The systematic framework is distinguished } \\
\text { with flexibility and ease of communication. }\end{array}$ & 49 & 49 & 42 & 42 & 7 & 7 & 2 & 2 & 0 & 0 \\
\hline 7 & $\begin{array}{l}\text { The management of the bank has good } \\
\text { knowledge in the strategic analysis. }\end{array}$ & 54 & 54 & 38 & 38 & 6 & 6 & 2 & 2 & 0 & 0 \\
\hline \multicolumn{2}{|c|}{ Total } & 390 & 55.7 & 246 & 35.1 & 47 & 6.6 & 16 & 2.3 & 1 & 0.1 \\
\hline
\end{tabular}

Table 7 above shows that $90.8 \%$ of the sample agreed on all items that addressed the relationship between the senior management's understanding, applying, and practicing the strategic management techniques, and achievement of the competitive advantage while the those who disagreed on this relationship were $2.4 \%$. The percentage of those who were neutral was $6.6 \%$.

\subsubsection{Descriptive Analysis of the $1^{\text {st }}$ Hypothesis Items}

Table 8 below shows the $M, S D$, and $\%$ and $R$ of the items in accordance with the sample's responses. If the real mean of the items is greater than the assumed mean (3) and the percentage is greater than $60 \%$, the item is positive (i.e., it is agreed upon by the sample). However, If the real mean of the items is less than the assumed mean (3) and the percentage is less than $60 \%$, the item is negative (i.e., it is disagreed upon by the sample).

Table 8 Analysis of the $2^{\text {nd }}$ Hypothesis statements

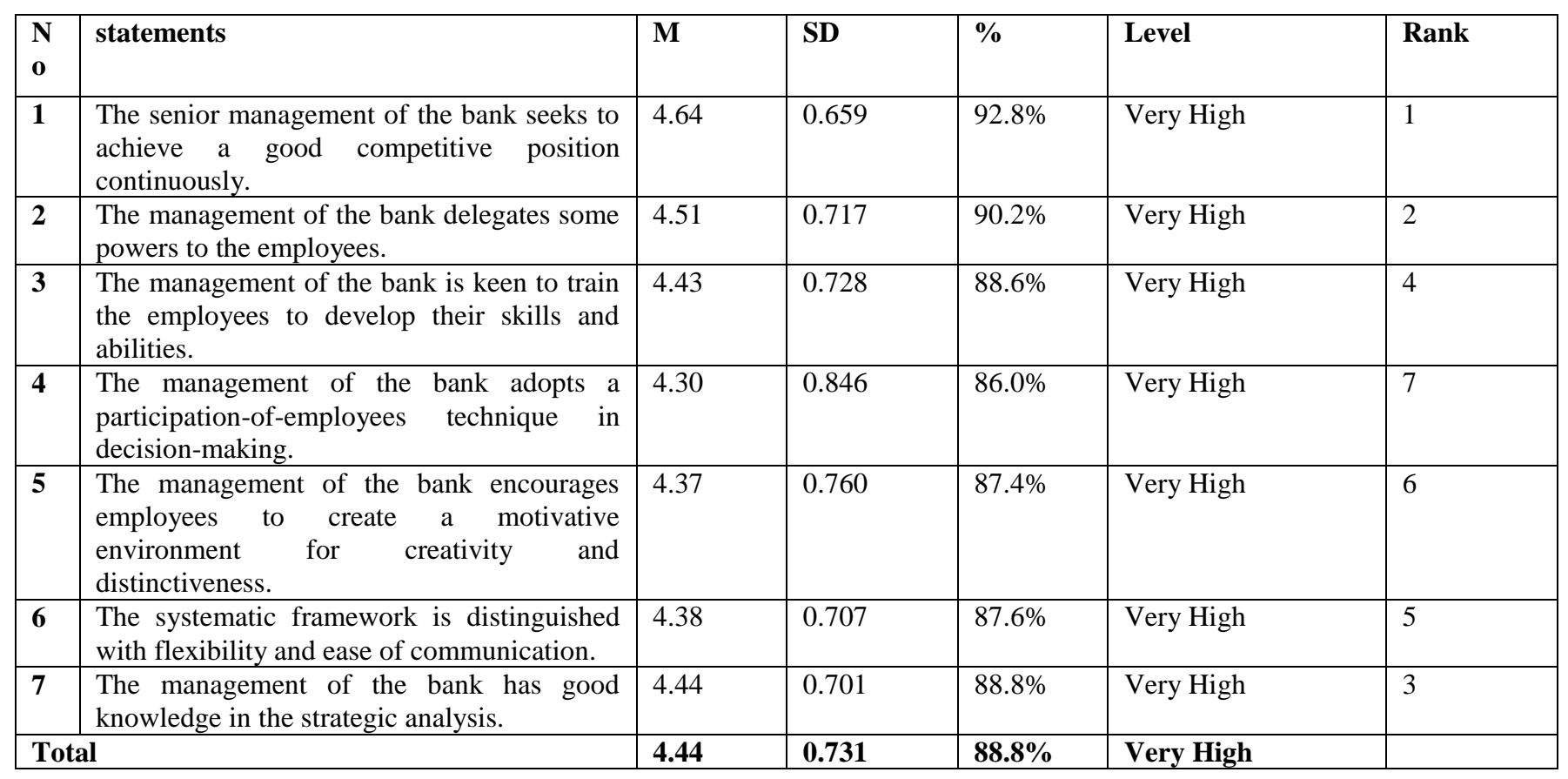




\subsubsection{Square Chi Test}

To identify whether or not there were statistically significant differences between the those who agreed and those who disagreed upon items, Chi-square test was used. The results of the test are shown in Table 9 below:

Table 9 Results of Square Chi Test

\begin{tabular}{|l|l|l|l|l|l|l|}
\hline No & statements & $\begin{array}{l}\text { Chi } \\
\text { Value }\end{array}$ & DF & T-Value & p-value & $\boldsymbol{P}$ \\
\hline $\mathbf{1}$ & $\begin{array}{l}\text { The senior management of the bank seeks to achieve a good } \\
\text { competitive position continuously. }\end{array}$ & 125.3 & 3 & 7.81 & 0.000 \\
\hline $\mathbf{2}$ & $\begin{array}{l}\text { The management of the bank delegates some powers to the } \\
\text { employees. }\end{array}$ & 90.8 & 3 & 7.81 & 0.000 & Significant \\
\hline $\mathbf{3}$ & $\begin{array}{l}\text { The management of the bank is keen to train the employees } \\
\text { to develop their skills and abilities. }\end{array}$ & 72.7 & 3 & 7.81 & 0.000 & Significant \\
\hline $\mathbf{4}$ & $\begin{array}{l}\text { The management of the bank adopts a participation-of- } \\
\text { employees technique in decision-making. }\end{array}$ & 52.4 & 3 & 7.81 & 0.000 \\
\hline $\mathbf{5}$ & $\begin{array}{l}\text { The management of the bank encourages employees to } \\
\text { create a motivative environment for creativity and } \\
\text { distinctiveness. }\end{array}$ & 114.0 & 4 & 9.48 & 0.000 \\
\hline $\mathbf{6}$ & $\begin{array}{l}\text { The systematic framework is distinguished with flexibility } \\
\text { and ease of communication. }\end{array}$ & 68.7 & 3 & 7.81 & 0.000 \\
\hline $\mathbf{7}$ & $\begin{array}{l}\text { The management of the bank has good knowledge in the } \\
\text { strategic analysis. }\end{array}$ & 76.0 & 3 & 7.81 & 0.000 \\
\hline Total & Significant & Significant \\
\hline
\end{tabular}

\subsubsection{Discussion of the results of the $2^{\text {nd }}$ Hypothesis}

Table 7 shows that the majority of the sample agreed on all items designed to address the $2^{\text {nd }}$ hypothesis. All their responses were positive in that the percentage of their total agreement shown in the frequency distribution of the $2^{\text {nd }}$ hypothesis was $(90.8 \%)$. This percentage indicates that they totally agreed on the contents of the hypothesis in that the level of the agreement was very high. This indicates that all sample agreed on the relationship between the senior management's understanding, applying, and practicing the strategic management techniques, and achievement of the competitive advantage.

Table 8 shows that the total $M$ of all items of the hypothesis was greater than the assumed mean (3) according to Likert Scale. This indicates that the attitudes of the sample were positive in that the sample agreed on all items of the hypothesis, $M=4.44, S D=0.731, \%=88.4$ (very high). This indicates that the majority of the sample agreed on the relationship between the senior management's understanding, applying, and practicing the strategic management techniques, and achievement of the competitive advantage.

Table 9 shows that, based on Chi-square, there were statistically significant differences among items in that the total value of Chi-square of all items was 85.7 at the level $0.000<0.05$. Therefore, there were statistically significant differences between the sample's responses in favor of those who agreed on the items at a very high level of response.

Therefore, based on data analysis, the $2^{\text {nd }}$ hypothesis "there was a statistically significant relationship between the senior management's understanding, applying, and practicing the strategic management techniques, and achievement of the competitive advantage " was accepted at a very high level of response.

\section{Recommendations}

\subsection{Recommendations of the Study}

The study recommended that:

1. Identifying the proper strategies that suit the bank under changing environmental conditions.

2. There should be a scientific selection for the management leaderships of banks in accordance with the standards of efficiency and major.

3. Each bank should revise its mission and objectives and/to involve some important elements such as quality, research, and development, pay attention to human resources, and meet its customers' needs.

4. Banks should cultivate the concept of mission with all employees. 
5. Banks should rely on the administration of the comprehensive quality as a modern management technique for the sake of an ongoing improvement.

6. Paying attention to the three types of business strategies that depend on the scientific techniques.

7. Utilizing from both experts and creative people working in the banks, the sample of the study.

8. Developing the employees' skills in designing, implementing, and controlling strategies.

9. Training and qualifying the administrative leaderships at the Sudanese banks in exercising/practicing the strategic management, strategic planning, and environmental analysis in order to live up to deal with current and future challenges.

\subsection{General Recommendations}

1. Paying attention to the strategic management as being a basic tool for reducing risks and gaps and supporting the strength points.

2. Paying attention to conducting studies and researches should be encouraged, enough annual budgets should be specified to develop the scientific research for identifying the points of strength and weaknesses, opportunities, threats and the improvement plans.

3. There should be specialized managements in both strategic planning and analysis of internal and external environments at the Sudanese banks.

4. Enacting the role of the strategic control at the Sudanese banks, removing its application barriers and providing proper solutions for them.

5. Closing workshops on quality and strategic management at the Sudanese banks.

6. Paying attention to the strategic thought to remove bureaucracy at the banks. This can be achieved by delegating powers.

7. Using research and educational centers in the fields of research and development in order to solve problems.

\section{References}

Abdulmottaleb, A. (2010). Strategic management in business environment. Cairo, Egypt: United Arab Company for Marketing and Import.

Abu Qenayah, A. (2002). Concepts of strategic management the management leaderships and their effect on developing the performance of enterprises (Unpublished PhD dissertation). Sudan: Faculty of Graduates, AlKhartoum University.

Ahmed, O., \& Al-Awada, W. (2011). The relationship between the strategic information system and the competitive advantage. Journal of Tashreen University for Research and Scientific Studies, 33(4).

Al-Ameri, A. (2006). Strategy and its effect on developing the performance of the Islamic banks in Yemen. (Unpublished $\mathrm{PhD}$ dissertation). University of Neelain.

Al-Attoom, M. (2009). Organization mission and its effect on achieving the competitive advantage (M.A thesis). University of Middle East for Higher Studies.

Al-Moshari, A. (2004). The effect of strategic management on the sector of cement industry in the Kingdom of Saudi Arabia (Unpublished PhD dissertation). Sudan: Sudan University for Science and Technology.

Al-Najjar, F. (2000). Competition and applied propaganda: Allies for improving the competitive centers. Alexandria: Shabab Al-Jamea'a Publication Institution.

Al-Roosan, M. (2007). The relationship between the competitive advantage and the environmental analysis: A study applied on the Jordanian banking sector. Journal of Management and Economy, 63, p.80.

Al-Samiri, M. (2000). Marketing strategies. Oman: Dar Al-Hamed.

Haidar, M. (2002). Information system: An approach to achieve the competitive advantage. Cairo: Al-Dar Al-Jameiah for Publication.

Harharah, H. (2008). The effect of applying the strategic management approach on the performance of trade banks in the United Arab of Emirate (PhD dissertation). Sudan: Sudan University for Science and Technology.

Lee, R. (2008). Strategic management: competitive advantage development (Translated by Al- A. Khozami). Ben: Dar Al-Fagr Distribution and Publication.

Othman, D. (2017). Strategic planning and its role in achieving a competitive advantage in the operating telecommunication companies in Sudan (M.A thesis). Faculty of Graduates, University of Neelain. 
Redhwan, M. (2011). Competitiveness as an ally of the economic globalization and its role in supporting the efforts of development in the world ( $1^{\text {st }}$ ed.). Egypt: Al-Dar Al-Jameiah.

Tabidi, M. (2010). The effect of strategic management on proficiency and effectiveness of performance: A case study on the Sudanese telecommunication companies (Unpublished $\mathrm{PhD}$ dissertation). Al-Khortoum University.

Shamat, N. (2010). International competitiveness and its effect on Arab and world trade ( ${ }^{\text {st }}$ ed.). Alexandria: Dar AlTa'aleem Al-Jamei for Publication and Distribution. 